УДК 657.1

\title{
ОБЛІКОВО-АНАЛІТИЧНЕ ЗАБЕЗПЕЧЕННЯ УПРАВЛІННЯ ВІДХОДАМИ ВИРОБНИЦТВА БОРОШНОМЕЛЬНОЇ ГАЛУЗІ
}

\section{ACCOUNTING AND ANALYTICAL PROVISION OF WASTE MANAGEMENT OF THE FLOUR MILLING INDUSTRY}

\author{
Колісник Олена Пилипівна \\ кандидат економічних наук, доцент, \\ Університет державної фріскальної служби України \\ ORCID: https://orcid.org/0000-0003-1755-5638 \\ Kolisnyk Olena \\ University of State Fiscal Service of Ukraine
}

\begin{abstract}
Стаття присвячена актуальним питанням формування обліково-аналітичного забезпечення управління відходами виробництва борошномельної галузі. Відходи утворюються у процесі виробництва чи споживання. Вони повністю або частково втратили свої початкові споживчі властивості і не мають подальшого використання за місцем їх утворення чи виявлення. Як правило, власник позбувається або має намір чи повинен позбутися відходів шляхом їх утилізації чи видалення. Борошномельна галузь належить до числа галузей, у яких технологія виробництва передбачає як вихід основної продукції, так і утворення достатньої питомої ваги побічної продукції та виробничих відходів. У статті проаналізовано основні підходи та напрями дослідження в сфері зернопереробного виробництва. Визначено особливості класифікації відходів виробництва. Досліджено та згруповано принципи обліку відходів при виробництві продукції борошномельними підприємствами. Важливим питанням $€$ визначення впливу величини виробничих відходів на собівартість виготовленої продукції. Важливою умовою есрективного використання відходів виробництва є їх обов'язкове оприбуткування, оскільки це впливає на зниження собівартості виробленої продукції. Розкрито питання синтетичного обліку відходів, які утворюються на зернопереробних підприємствах. Обгрунтовано необхідність фрормування інформації про кількість і вартість відходів та їх види у розрізі місць виникнення відходів. Крім того, увагу приділено питанню фрормування інформації про види сировини, з якої отримані відходи. Для цього потрібен документ, який повністю забезпечує менеджмент підприємства інформацією про відходи, тобто забезпечує більш детальний аналітичний облік. Для обліку руху виробничих відходів пропонується спеціальна відомість, яка представляє собою кількісний та вартісний баланс відходів борошномельного виробництва. Цей баланс містить інформацію про назву відходів, їх залишки на початок та кінець звітного періоду. Баланс також містить дані щодо кількості та вартості відходів, які були оприбутковані та використані для потреб виробництва основної продукції, та про відходи, які використані в якості пального та для інших власних потреб, або були втрачені при зберіганні чи реалізовані. Важливим питанням є оцінка виробничих відходів, при цьому вид оцінки залежить від часу здійснення цього процесу. Можна виділити такі види оцінок: оцінка при оприбуткуванні з виробництва; оцінка при відпуску у подальшу переробку на самому підприємстві; оцінка виробничих відходів при реалізації.
\end{abstract}

Ключові слова: відходи виробництва, управління відходами, зворотні відходи, відходи борошномельної галузі, класифікація відходів, оцінка відходів.

Статья посвящена актуальным вопросам фрормирования учетно-аналитического обеспечения управления отходами производства мукомольной отрасли. Отходы образуются в процессе производства или потребления. Они полностью или частично потеряли свои первоначальные потребительские свойства и не имеют дальнейшего использования по месту их образования. Как правило, владелец избавляется или намеревается избавиться от отходов путем их утилизации. Мукомольная отрасль относится к числу отраслей, в которых технология производства предусматривает как выход основной продукции, так и образования достаточного удельного веса побочной продукции и производственных отходов. В статье проанализированы основные подходы и направления исследования в сфере зерноперерабатывающего производства. Определены особенности классификации отходов производства. Исследованы и сгруппированы принципы учета отходов при производстве продукции мукомольных предприятий. Важным вопросом является определение влияния 
величины производственных отходов на себестоимость произведенной продукции. Важным условием эффективного использования отходов производства является их обязательное оприходование, поскольку это влияет на снижение себестоимости продукции. Раскрыты вопросы синтетического учета отходов, которые образуются на зерноперерабатывающих предприятиях. Обоснована необходимость фрормирования информации о количестве и стоимости отходов и их виды в разрезе мест возникновения отходов. Кроме того, внимание уделено вопросу формирования информации о видах сырья, из которого получены отходы. Для этого нужен документ, который полностью обеспечивает менеджмент предприятия иноормацией об отходах, то есть обеспечивает более детальный аналитический учет. Для учета движения производственных отходов предлагается специальная ведомость, которая представляет собой количественный и стоимостный баланс отходов мукомольного производства. Этот баланс содержит инорормацию о названии отходов, их остатки на начало и конец отчетного периода. Баланс также содержит данные о количестве и стоимости отходов, которые были оприходованы и использованы для нужд производства основной продукции, и об отходах, которые использованы в качестве топлива и для других собственных нужд, или были утрачены при хранении или реализованы. Важным вопросом является оценка производственных отходов, при этом вид оценки зависит от времени осуществления этого процесса. Можно выделить следующие виды оценок: оценка при оприходовании из производства; оценка при отпуске в дальнейшую переработку на самом предприятии; оценка производственных отходов при реализации.

Ключевые слова: отходы производства, управления отходами, возвратные отходы, отходы мукомольной отрасли, классификация отходов, оценка отходов.

The article is devoted to topical issues of formation of accounting and analytical support of waste management of the flour milling industry. Waste is generated in the process of production or consumption. They have completely or partially lost their original consumer properties and have no further use at the place of their formation or detection. As a rule, the owner disposes or intends or must dispose of waste by utilization or removal of it. The flour milling industry is one of the industries in which the production technology provides for both the output of the main product and the formation of a sufficient share of by-products and industrial waste. The article analyzes the main approaches and areas of research in the field of grain processing. Peculiarities of production waste classification are determined. The specifics of accounting for returnable waste, which have the largest share in the waste of flour milling businesses, have been studied. The principles of waste accounting in the production of flour milling businesses have been studied and grouped. An important issue is to determine the impact of the amount of industrial waste on the cost of manufactured products. An important condition for the efficient use of industrial waste is its mandatory posting, as it reduces the cost of production. At the same time, it is necessary to link the process of documenting the facts of occurrence the waste with the peculiarities of production technology and technical documentation. The issue of synthetic accounting of waste generated at grain processing enterprises is revealed. The necessity of forming information about the quantity and cost of waste and their types in terms of waste generation places is substantiated. In addition, attention is paid to the formation of information about the types of raw materials from which waste is obtained. This requires a document that fully provides the management of the company with information about waste, ie provides more detailed analytical accounting. To account for the movement of industrial waste, a special statement is proposed, which is a quantitative and cost balance of waste from flour milling production. This balance contains information on the name of the waste, its balances at the beginning and end of the reporting period. The balance also contains data on the amount and value of waste that has been accounted for and used for the production of basic products, and on waste that has been used as fuel and for other own needs, or has been lost during storage or sold. An important issue is the assessment of industrial waste, and the type of assessment depends on the time of this process. The following types of assessments can be distinguished: assessment in posting from production; assessment during the release for further processing at the enterprise; assessment of industrial waste during sales.

Keywords: production wastes, waste management, returnable wastes, wastes of flour milling industry, waste classification, waste estimation.

Постановка проблеми. Розвиток законодавства у сорері охорони природного навколишнього середовища спонукає суб'єктів господарювання до постійного удосконалення підходів щодо забезпечення раціонального природокористування та охорони навколишнього середовища, у т.ч. сорери поводження 3 відходами. В Україні спостерігається складна ситуація з утворенням, накопиченням, зберіганням, переробкою, утилізацією та захороненням відходів, що має певні екологічні загрози та виклики. Доволі критичну оцінку системи обліку і звітності щодо відходів нада- ють фрахівці. Обов'язковою умовою ефективного управління відходами є їх облік на всіх стадіях життєвого циклу (утворення, збір, накопичення, транспортування, переробка, утилізація, знешкодження, захоронення). Саме тому, дослідження питання обліковоаналітичного забезпечення управління відходами в системі управління підприємством наразі $€$ своєчасним та актуальним.

Аналіз останніх досліджень і публікацій. Дослідженню питань обліково-аналітичного забезпечення управління відходами, зокрема їх класифікація, оцінка та організація обліку, 
присвячено прації науковців, серед яких Герасимович А.М., Гуцайлюк 3.В., Замула І.В., Сопко В.В. та інші. Проте, питання формування обліково-аналітичного забезпечення управління відходами, як цілісної системи, залишається не вирішеним, оскільки має низку суттєвих проблем, як методичного характеру так і незацікавленістю суб'єктів господарювання у подальшій їх переробці.

Виділення невирішених раніше частин загальної проблеми. Питання обліку виробничих відходів борошномельної галузі розглядалося з огляду їх впливу на собівартість виготовленої продукції. У статті досліджено їх оцінку з урахуванням подальшого використання та вмістом корисних речовин.

Формулювання цілей статті (постановка завдання). Основною ціллю статті $\epsilon$ дослідження питань фрормування обліковоаналітичного забезпечення управління відходами виробництва борошномельної галузі. Необхідність визначення завдань, які повинен виконувати бухгалтерський облік для забезпечення сталого розвитку суб'єктів господарювання, зумовлена повною трансформацією організаційно-методологічних засад, орієнтованих на фрормування економіко-екологічного підходу до інформації та системи управління підприємством.

Виклад основного матеріалу дослідження. Основними принципами державної політики у сорері поводження 3 відходами $\epsilon$ пріоритетний захист навколишнього природного середовища та здоров'я людини від негативного впливу відходів, забезпечення ощадливого використання матеріально-сировинних та енергетичних ресурсів, науково обґрунтоване узгодження екологічних, економічних та соціальних інтересів суспільства щодо утворення та використання відходів 3 метою забезпечення його сталого розвитку. До таких принципів належить і обов'язковий облік відходів на основі їх класифрікації та паспортизації [1].

Відходи - будь-які речовини, матеріали і предмети, що утворилися у процесі виробництва чи споживання, а також товари (продукція), що повністю або частково втратили свої споживчі властивості і не мають подальшого використання за місцем їх утворення чи виявлення і від яких їх власник позбувається, має намір або повинен позбутися шляхом утилізації чи видалення [2].

Борошномельна галузь належить до числа галузей, де технологія виробництва передбачає разом з виходом основної продукції утво- рення достатньої питомої ваги побічної продукції та виробничих відходів.

Інтенсифікація виробництва визначається комплексною переробкою матеріальних ресурсів, враховуючи при цьому повне використання всіх відходів, що утворюються. Для управління рухом і використанням відходів необхідна відповідна інсрормаційна база, яка формується в основному у бухгалтерському обліку. Попередньою умовою організації обліку вторинних матеріальних ресурсів $€$ визначення його об'єктів. При цьому, дуже важливо розмежовувати сутність таких понять як «відходи виробництва» та «побічна продукція».

До зворотніх відходів не належить побічна продукція, що одержується одночасно з цільовим (основним) продуктом в єдиному технологічному процесі.

3 огляду подальшого використання, виробничі відходи поділяють на зворотні і незворотні. Зворотні відходи розподіляються на такі, що використовуються та не використовуються у виробництві.

До зворотніх відходів, що використовуються у виробництві, відносять відходи, які можуть бути спожиті самим підприємством для виготовлення продукції основного або допоміжного виробництва.

До зворотніх відходів що не використовуються у виробництві, вважаються відходи, які можуть бути спожиті самим підприємством лише у якості матеріалів, палива, на інші господарські потреби або реалізовані на сторону.

До зворотніх відходів належать залишки сировини, матеріалів, напівфрабрикатів, теплоносіїв та інших видів матеріальних ресурсів, що утворилися в процесі виробництва продукції (робіт, послуг), втратили повністю або частково споживчі властивості початкового ресурсу (хімічні та фрізичні) і через це використовуються з підвищеними витратами (зниженням виходу продукції) або зовсім не використовуються за прямим призначенням.

Незворотніми вважаються відходи, які не можуть бути використані при даному стані технічного оснащення, та технологічні втрати: усушка, механічні втрати, непридатні відходи тощо. Якщо на борошномельних підприємствах окремі види лузги знешкоджуються (спалюються або вивозяться на смітник), то її слід віднести до незворотніх відходів.

Основною умовою організації обліку виробничих відходів $€$ виявлення і правильне визначення впливу їх величини на собівартість виготовленої продукції. Так, збільшення 
кількості оприбуткованих з виробництва відходів безпосередньо впливає на величину собівартості виробленої продукції в сторону її зниження. Проте, їх наявність свідчить про недосконалість технологічного процесу, і як наслідок, про збільшення витрачання основних видів сировини і матеріалів у порівнянні 3 необхідною речовинною основою виробів. Окрім того, повне оприбуткування відходів та їх подальше ефективне використання впливає на кінцеві фрінансово-господарські результати діяльності підприємства.

Відходи виробництва $€$ різновидом матеріальних ресурсів та представляють об'єкт бухгалтерського обліку. Очевидним $€$ те, що їх обліково-аналітичне забезпечення, залежить від специсріки технології і організації виробництва, виду відходів, способу їх отримання та особливостей наступного зберігання.

До загальних принципів обліку відходів слід віднести: обов'язковість оприбуткування; чіткий (налагоджений) облік руху; науково обгрутована оцінка; облік процесу переробки; облік процесу реалізації; розрахунок впливу величини і вартості відходів на собівартість основних продуктів; облік ефективності використання відходів.

Важливою умовою подальшого ефективного використання відходів виробництва $\epsilon$ ïх обов'язкове оприбуткування, а повнота оприбуткування безпосередньо впливає на зниження собівартості виробленої продукції. Одночасно необхідно максимально пов'язати процес документування фрактів виникнення відходів з особливостями технології виробництва і технічної документації, що використовується, а також системою матеріального стимулювання, в іншому випадку оприбуткування вторинних матеріальних ресурсів буде неповним.

Набагато складніше організувати облік оприбуткування відходів, якщо иникає необхідність обліковувати не тільки їхню кількість, а й вміст корисних речовин.

Виникнення відходів відбувається у ході технологічного процесу і їх величина фріксується, зазвичай, одразу по ходу виробництва в технічній документації, тобто посередництвом технологічного обліку і контролю.

На борошномельних підприємствах відходи утворюються залежно від виду проведення операцій із зерном.

При надходженні зерна на елеватор чи хлібоприймальну дільницю, лабораторія визначає його якісні характеристики. Зазвичай, зерно не відповідає стандартним показни- кам, і як правило, містить зернових домішок більше норми та підвищену вологість. Для приведення зерна до встановлених кондицій проводять його очищення та сушіння, в результаті чого утворюються відходи, які підлягають оприбуткуванню.

Синтетичний облік зворотніх відходів (для борошномельних підприємств це лузга) ведеться в системі рахунків бухгалтерського обліку, проте їх оприбуткування не відображається на спеціальному рахунку і проводиться запис:

1) Дебет 801 «Витрати сировини й матеріалів»

Кредит 201 «Сировина й матеріали»

2) Дебет 231 «Основне виробництво»

Кредит 801 «Витрати сировини й матеріалів» - списане зерно, направлене у основне виробництво на переробку.

Одночасно, на цю кореспонденцію рахунків проводиться червоним сторно сума відходів.

Для подальшого їх використання робиться запис:

1) Дебет 203 «Паливо»

Кредит 201 «Сировина й матеріали» - відходи за накладною внутрішнього переміщення переводяться до пального;

2) Дебет 208 «Матеріали сільськогосподарського призначення»

Кредит 201 «Сировина й матеріали» - відходи передані у підсобне господарство.

Відсутність окремого рахунку для оприбуткування відходів не сприяє покращенню процесу управління відходами. Доцільним $\epsilon$ ведення окремого субрахунку «Відходи виробництва» на рахунку 209 «нші матеріали». За дебетом цього рахунку повинні фріксуватися надходження зворотніх відходів, а за кредитом, їх використання.

Бухгалтерський облік виробничих відходів, не повинен обмежуватися лише їх оприбуткуванням 3 виробництва. Важливою управлінською інфрормацією $€$ дані про наявність відходів на складі у розрізі їх окремих видів, відповідності нормативу тощо. Облік наявності виробничих відходів на складі (в цеху відходів) здійснюється аналогічно обліку інших матеріальних цінностей.

Кількісно-якісний облік відходів, що надійшли на склад, ведуть згідно з виробничим переважуванням, а якісні показники - за даними лабораторії отримувача. Відходи, яі утворюються в результаті переробки зерна на борошномельних підприємствах класифрікують за такими видами (табл. 1).

Інфрормацію про величину і вартість відходів за їх видами, видами сировини, із якої 
Таблиця 1

Класифрікація відходів зернопереробного виробництва

\begin{tabular}{|c|c|c|}
\hline $\begin{array}{l}\text { № } \\
3 / \Pi\end{array}$ & $\begin{array}{c}\text { Вид відходів } \\
\text { за категоріями }\end{array}$ & Класифрікація відходів \\
\hline 1. & $\begin{array}{l}\text { Відходи першої } \\
\text { категорії }\end{array}$ & $\begin{array}{l}\text { - зернові відходи з вмістом зерна понад 30\% до 50\% (включно); } \\
\text { - зернові відходи з вмістом зерна понад 10\% до 30\% (включно); } \\
\text { - борошняні витруски і підзміт; } \\
\text { - пил вибійний (білий). }\end{array}$ \\
\hline 2. & $\begin{array}{l}\text { Відходи другої } \\
\text { категорії }\end{array}$ & $\begin{array}{l}\text { - зернові відходи з вмістом зерна понад 2\% до 10\%; } \\
\text { - стрижні качанів кукурудзи, кукурудзяна плівка, лузга горохова, } \\
\text { лузга м'яка вівсяна і ячмінна, полова; } \\
\text { - пил вибійний (сірий). }\end{array}$ \\
\hline 3. & $\begin{array}{l}\text { Відходи третьої } \\
\text { категорії }\end{array}$ & $\begin{array}{l}\text { - відходи від зачистки зерна («схід» з приймального сита } \\
\text { сепаратора, прохід через нижнє сито сепаратора), що містять не } \\
\text { більше } 2 \% \text { зерна, соломисті частки; } \\
\text { - лушпиння рисове, просяне, гречане, жорстке вівсяне і ячмінне, пил } \\
\text { аспіраційний і вибійний чорний; } \\
\text { - кукурудзяні обгортки. }\end{array}$ \\
\hline
\end{tabular}

вони отримані, необхідно орормувати і за місцями виникнення. Для цього потрібен документ, який повністю забезпечує інформацією про відходи, тобто більш детальний аналітичний облік. Для обліку руху виробничих відходів можна запропонувати спеціальну відомість, яка представляє собою кількісний та вартісний баланс відходів борошномельного виробництва, який містить інформацію про назву відходів, залишки на початок та кінець звітного періоду, кількість та вартість відходів по оприбуткуванню та їх використанню для потреб: виробництва основної продукції, в якості пального, інших власних потреб, втрати при зберіганні та реалізації на сторону.

Специфріка зернопереробного виробництва не дозволяє повністю використовувати всі корисні речовини, що містяться у сировині (зерні) - частина їх все одно втрачається. Таким чином, незворотні відходи являють собою кінцеві виробничі втрати для підприємства. Незворотні відходи 3 виробництва не оприбутковуються через економічну недоцільність або неможливість подальшого використання і відсутності вартісної оцінки. Вони, доречі, є об'єктами технологічного, а не бухгалтерського обліку.

Отримані в ході технологічного циклу виробничі відходи підлягають не тільки кількісному відображенню, а й вартісній оцінці. Тому, дуже важливим моментом управління виробничими відходами є їх науково обгрунтована оцінка, тобто переведення вимірника із кількісного у вартісний. Ціна відходів повинна встановлюватися з врахуванням вмісту корисних речовин. А в основу оцінки виробничих відходів повинен бути покладений прин- цип можливостей їх подальшого використання з якомога більшою економічною вигодою.

Незважаючи на, здавалося б чітку оцінку виробничих відходів, навряд чи можна стверджувати, що це питання повністю вирішене на практиці. Передусім мова йде про наукове обґрунтування цієї оцінки і відображенні вартості виробничих відходів в калькуляціях собівартості основної продукції.

На жаль, найбільш хибним моментом у визначенні ціни на виробничі відходи $€$ неповний підрахунок всіх пов'язаних з цим витрат. Необхідно розрізняти декілька видів оцінки виробничих відходів. Вибір того чи іншого виду оцінки залежить від часу здійснення цього процесу. Маються на увазі часові моменти:

- оцінка виробничих відходів при їх оприбуткуванні з виробництва;

- оцінка виробничих відходів при відпуску у подальшу переробку на самому підприємстві;

- оцінка виробничих відходів при реалізації стороннім покупцям.

Зрозуміло, що вартісна оцінка відходів при їх виникненні буде відрізнятися від оцінки при їх передачі для подальшої переробки або реалізації, оскільки при двох останніх випадках з'являється ряд додаткових витрат, тобто в процесі подальшого використання виробничих відходів вже необхідно визначати їх собівартість. Кожне підприємство при встановленні цін на відходи враховує в першу чергу попит - пропозицію на ринку зерна та зернопродуктів. Проте, єдиної методики для визначення цін на відходи не відпрацьовано, що дає можливість підприємствам безконтрольно варіювати цінами на відходи.

Необхідно зазначити, що ціни на виробничі відходи повинні будуватися в першу чергу на 
величині вмісту корисних речовин та можливостях подальшого використання. Іноді на практиці, ціни встановлюються без врахування цих фракторів.

Висновки. Вважаємо, що розгляд особливостей обліково-аналітичного забезпечення управління відходами, які утворюються у борошномельній галузі, із врахуванням викладених вище пропозицій буде сприяти удосконаленню його організації. Важливими $є$ питання правильного оприбуткування, обліку руху, використання та реалізації відходів, і що не менш важливо науково обґрунтована оцінка, яка впливає на рівень собівартості продукції борошномельної галузі і тим самим визначає розмір прибутку.

\section{СПИСОК ВИКОРИСТАНИХ ДЖЕРЕЛ:}

1. Облік відходів: питання та перспективи. URL: https://ecolog-ua.com/news/oblik-vidhodiv-pytannya-taperspektyvy

2. Про відходи : Закон України від 05.03.1998 р. № 187/98-BP. URL: https://zakon.rada.gov.ua/laws/show/ 187/98-\%D0\%B2\%D1\%80\#Text

\section{REFERENCES:}

1. Oblik vidkhodiv: pytannja ta perspektyvy. URL: https://ecolog-ua.com/news/oblik-vidhodiv-pytannya-taperspektyvy

2. Pro vidkhody: Zakon Ukrajiny vid 05.03.1998 r. № 187/98-VR. URL: https://zakon.rada.gov.ua/laws/show/ 187/98-\%D0\%B2\%D1\%80\#Text 